2

\title{
Student Learning Experiences and Outcomes in
} The Mississippi State University College of Veterinary Medicine Shelter Medicine Program

\author{
Jacob M. Shivley ${ }^{1, *}$, Cooper W. Brookshire ${ }^{2}$, Philip A. Bushby ${ }^{3, *}$ and Kimberly A. Woodruff ${ }^{4}$ \\ 1 Mississippi State University, College of Veterinary Medicine, PO Box 6001, Miss State, MS 39762 \\ j.shivley@msstate.edu \\ 2 Mississippi State University, College of Veterinary Medicine, PO Box 6001, Miss State, MS 39762 \\ c.brookshire@msstate.edu \\ 3 Mississippi State University, College of Veterinary Medicine, PO Box 6001, Miss State, MS 39762 \\ bushby@cvm.msstate.edu \\ 4 Mississippi State University, College of Veterinary Medicine, PO Box 6001, Miss State, MS 39762 \\ kwoodruff@cvm.msstate.edu \\ * Correspondence: bushby@cvm.msstate.edu; Tel.: +1-662-325-5157; Fax: +1-662-325-4011;
}

j.shivley@msstate.edu; Tel: +1-662-325-3432; Fax: +1-662-325-4596

\begin{abstract}
While referral-level medicine is important in the veterinary curriculum, students also need a solid base knowledge of clinically relevant routine surgery and diagnostic skills. Veterinary hospitals must maintain a steady caseload that provides wellness cases and commonly encountered conditions. Shelter Medicine programs can create the opportunities to meet these challenges. Students can gain quantifiable surgical experience in spay/neuter with measured growth in surgical efficiency and competency while providing needed community service for animal shelters. Students can directly interact with shelter animals by performing examinations, diagnostic testing, and development of treatment protocols and recommendations for commonly encountered problems. Furthermore, students can obtain a working knowledge of biosecurity on a population level to minimize risk of infectious diseases spreading to healthy populations.
\end{abstract}

Keywords: shelter medicine; animal sheltering; shelter surgery; veterinary medical education; veterinary student training; population medicine; biosecurity

\section{Introduction}

Mississippi State University College of Veterinary Medicine (MSU-CVM) is located in Starkville, MS, with a population of about 25,000. The closest metropolitan area in the state is 130 miles away (Jackson, MS with a population of about 170,000). Even with a solid referral case load for specialty services, there can be challenges in receiving adequate numbers of primary/first opinion cases.[1] While referral-level medicine is important in the veterinary curriculum, students also need a solid base knowledge of clinically relevant routine surgery and diagnostics.[2] The MSU-CVM Shelter Medicine program fills the case load gap by creating opportunities with shelter animals to perform high quality/high volume spay/neuter (HQHVSN), physical examinations and hundreds of basic diagnostic tests, effectively adding on average 9,000 cases a year to the overall hospital case load.

All services of the Shelter Medicine Program directly engage communities across Mississippi while providing best practice, high quality clinical instruction in surgery, medicine, and population medicine. Fourth-year veterinary students average 65 spay/neuter surgeries at 7 different animal shelters while on the Shelter Medicine spay/neuter elective. Students hone clinically relevant medical and diagnostic skills while participating in shelter medical days, and the population medicine rotation equips students with the knowledge and skills needed to understand the health 
needs of companion and food animals on a population level. This situational learning environment allows students to refine their newly developed surgical and medical skills while building relationships with animal caretakers in their community, which in turn fosters the mindset of a community veterinary practitioner.

\section{Shelter Surgery}

The MSU-CVM Shelter Medicine program has two mobile veterinary units that provide HQHVSN services to 26 different shelters and rescue groups in central and north Mississippi. The mobile unit program has sterilized over 70,000 animals since its inception in 2007, and has saved the lives of numerous animals by increasing adoption rates. In 2013, the collective euthanasia rate of the shelters serviced by Mississippi State was $62 \%$, but the adoption rate of the animals sterilized by the program was $82 \%$. By 2016 the collective euthanasia rate was $28.5 \%$, and the adoption rate of the animals sterilized was $88.5 \%$. While providing community and statewide service is a great benefit of the program, the main goals are to increase veterinary student surgical skills and confidence, while providing them with an understanding of the problems of pet overpopulation. This program provides two opportunities for students to increase surgical skills and confidence.

As part of a 6-week Community Veterinary Services (CVS) rotation, third year students are required to spend 2 days on the mobile units learning HQHVSN techniques under the direct supervision of a shelter medicine faculty member or resident. The goals of the mobile unit experience for third year students are to provide opportunities to perform multiple sterilization surgeries with direct surgical guidance and verbal and written feedback, and for students to become familiarized with the issues that animal shelters face, to be exposed to the problems encountered in animals confined to animal shelters, and to develop an increased understanding of the issues surrounding overpopulation of unwanted pets.

Prior to their first surgery day, all CVS students are required to view instructional videos of HQHVSN techniques in both pediatric and adult dogs and cats. The surgical techniques used are consistent with the standards outlined by the Association of Shelter Veterinarians 2016.[3] Students then perform surgeries with a faculty surgeon scrubbed in as their assistant, guiding them through the procedures and intervening to prevent complications. Each third-year CVS student averages 1520 sterilization surgeries in two trips, which helps to increase their surgical skills and confidence. Furthermore, they are exposed to current research projects evaluating surgical techniques in HQHVSN. Students are graded on multiple parameters and are provided with direct feedback both during surgery and after each trip. Preparation for surgery and surgical skills are evaluated using an objective structured assessment (Appendix A). Students are overwhelmingly positive about their experience on the mobile units, and most third year students then go on to enroll in a 2-week Shelter Medicine spay/neuter elective on the units during their fourth year.

Building upon the experience gained in the CVS rotation, the Shelter Medicine spay/neuter elective is a 2-week course in shelter surgery providing more in depth training. Fourth year students are given the time needed to become proficient and efficient in HQHVSN techniques under direct supervision and guidance of shelter medicine faculty. The course has two main goals: teaching and community service. Learning objectives include:

- Become proficient and efficient in spay/neuter techniques.

- Recognize the severity of pet overpopulation and how veterinarians can plan a role in solving the problem.

- Understand the standards of care in animal shelters.

- Understand the veterinary medical care guidelines for spay/neuter programs.

The elective is available nearly year-round and can enroll 115 students a year. A typical week consists of 4 trips on the mobile veterinary units to local shelters and 1 day of individual study. Working with faculty and house officers, students participate in the shelter spay neuter programs at various animal shelters, and in community spay day programs when available. Independent of the onsite shelter activities, the students: 
- View spay/neuter instructional videos prior to the first trip.

- Familiarize themselves with the drug protocols used on the mobile units.

- $\quad$ Read the document Guidelines for Standards of Care in Animal Shelters.[4]

- Read the document The Association of Shelter Veterinarians Veterinary Medical Care Guidelines for Spay-neuter Programs.[3]

- At the midpoint of the course, submit a self-evaluation to the instructor.

- At the end of the course, submit an examination to the instructor.

On the first day of the rotation, students scrub in with a faculty member and are guided through an adult dog neuter, adult dog spay, puppy spay, and cat spay. During this time, student preparation is directly assessed by the faculty member through questioning of surgical anatomy procedural details Afterwards, most students perform surgeries unassisted, while still under direct supervision of a faculty member. If complications arise, students are guided through appropriate measures to safely resolve the issue. Faculty members will step in to complete the surgery if the patients' health is at risk or if the surgery lasts longer than an hour. Allowing students to perform the surgeries and procedures without direct faculty assistance instills confidence and allows them to take responsibility for the surgical outcomes. Senior students are overwhelmingly positive about the surgical experience:

"Wonderful rotation that allowed me to gain confidence and experience in spays and neuters. I do not know what the first months out in practice would be like without having this valuable experience under my belt. Very thankful to all the clinicians and technicians that make this rotation one of the most valuable (in my opinion) rotation in vet school."

Students perform the clear majority of the spay/neuter surgeries on the mobile units, which total approximately 7,500 a year. On average, each fourth-year student performs 65 sterilizations during their two-week rotation (Table 1). The quantity of procedures allows students to develop a great increase in surgical confidence, efficiency, and proficiency. A retrospective study performed by the authors and their team examined 1,132 dog spays completed by 86 students. The 86 students performed a range of 1-46 surgeries (mean 9.8). Surgical times ranged from 8 to 153 minutes (mean 43.9). Linear regression demonstrated that the average surgical time for a student's first solo surgery (intercept) was 50.6 minutes and that surgical times decreased 0.61 minutes ( $p$ value $<.0001$ ) for each consecutive surgery performed by the individual student (Table 2).

Table 1. Average Case Log for Fourth Year Student on Shelter Surgery Elective

\begin{tabular}{|c|c|c|c|c|c|c|c|c|c|c|}
\hline Date & Shelter & $\begin{array}{l}\text { Kitten } \\
\text { neuter }\end{array}$ & $\begin{array}{c}\text { Cat } \\
\text { neuter }\end{array}$ & $\begin{array}{c}\text { Kitten } \\
\text { spay }\end{array}$ & $\begin{array}{c}\text { Cat } \\
\text { spay }\end{array}$ & $\begin{array}{l}\text { Puppy } \\
\text { neuter }\end{array}$ & $\begin{array}{c}\text { Dog } \\
\text { neuter }\end{array}$ & $\begin{array}{c}\text { Puppy } \\
\text { spay }\end{array}$ & $\begin{array}{l}\text { Dog } \\
\text { spay }\end{array}$ & Total \\
\hline $8 / 22 / 16$ & WestPoint & & & & 6 & 3 & & 2 & 1 & 12 \\
\hline $8 / 23 / 16$ & Macon & & 2 & & 1 & 1 & & 2 & 2 & 8 \\
\hline $8 / 25 / 16$ & $\mathrm{HB}$ & & 3 & & 2 & & 1 & 1 & & 7 \\
\hline $8 / 26 / 16$ & Aberdeen & & 1 & & 5 & & 2 & 1 & 2 & 11 \\
\hline $8 / 30 / 16$ & Starkville & & 2 & & 4 & 2 & 1 & 1 & 1 & 11 \\
\hline $9 / 1 / 16$ & Indianola & & 3 & & 5 & & 2 & 1 & 1 & 12 \\
\hline \multirow[t]{2}{*}{$9 / 2 / 16$} & Indianola & & & & 1 & 6 & & 3 & & 10 \\
\hline & & & & & & & & & & 71 \\
\hline
\end{tabular}


Table 2. Linear Regression Analysis for Student Surgical Time

\begin{tabular}{|c|c|c|c|c|c|}
\hline Effect & Estimate & $\begin{array}{l}\text { Standard } \\
\text { Error }\end{array}$ & $D F$ & $t$ Value & $P R>|t|$ \\
\hline Intercept & 50.5838 & 1.2682 & 85 & 39.89 & $<.0001$ \\
\hline order & -0.6070 & 0.08192 & 1044 & -7.41 & $<.0001$ \\
\hline
\end{tabular}

131

132

133

134

135

136

137

138

139

140

141

142

143

144

145

146

147

148

149

150

151

152

153

154

155

156

157

158

159

160

161

162

163

164

165

166

167

168

169

170

171

172

173

Student evaluations are accomplished through direct observation and a final examination. A mid-point self-evaluation encourages students to reflect on their strengths and weaknesses during surgery, and to identify areas where improvement is needed. A faculty member reviews each evaluation and responds with feedback on ways to improve during the second week. Final grades for the two-week rotation are determined by $80 \%$ instructor evaluation and $20 \%$ final examination. All faculty members provide an evaluation based on an objective structured assessment (Appendix B). The examination covers topics from the ASV guidelines for standards of care in animal shelters and the standards of care for spay/neuter programs.

\section{Shelter Medical Days}

Shelter medical days were created to provide students with practical diagnostic, technical and examination skills. Third year students attend 2-3 shelter medical days during their 6-week CVS rotation. During a shelter medical day trip, 3-5 veterinary students receive hands-on training though onsite shelter visits with a faculty member. Students interact directly with the supervising veterinarian during the examination, diagnostic testing, and development of treatment protocols and recommendations. In addition to direct patient care, students gain experience and skills in biosecurity, infection control within a population of animals, and animal behavior. Learning objectives include:

- Become proficient in canine and feline physical examinations techniques.

- Learn how to perform point of care diagnostic procedures.

- Develop treatment plans for individual shelter animals.

- Understand population medicine concepts as they relate to individual animal care.

- Recognize the severity of pet overpopulation and how veterinarians can play a role in solving the problem.

- Understand the standards of care in animal shelters.

Students visit numerous types of shelter models including privately and municipally funded shelters and both limited admission and open admission facilities. Shelter medical days begin with a brief introduction to the shelter system by the shelter veterinarian and shelter staff. Students perform a brief walkthrough evaluation of animals housed in the facility. Animals are selected for evaluation by students based on the needs of the shelter. Students perform intake examinations, routine wellness examinations, and sick-animal examinations under the direct supervision of a veterinarian. Students have access to the equipment needed for physical examinations and common point-of-care diagnostics. Physical examination equipment includes personal protective equipment, ophthalmoscopes, otoscopes, video otoscopes, thermometers, and stethoscopes. Point-of-care diagnostic supplies include needles, syringes, slides, microscopes, fecal flotation solution, scalpel blades, clear plastic tape, cytology staining liquids, blood collection tubes, and a Wood's lamp. Additional point-of-care diagnostics including parvovirus ELISA tests, heartworm antigen ELISA tests, and FIV/FELV ELISA tests are provided by the shelters. With these supplies, students perform and become proficient in numerous point-of-care diagnostics including fine needle aspiration with 
174 cytology, ear swab cytology, impression smear cytology, skin scrapings, tape-prep cytology, 175 venipuncture, Wood's lamp evaluation, fecal oocyte identification, and wet-mount microfilaria 176 evaluation. Students also perform routine procedures such as vaccine administration, anthelmintic 177 administration, ear cleaning, and wound care. Under the supervision of a veterinarian, students use 178 the information obtained from animal histories, physical examinations and diagnostic tests to make 179 further diagnostic and treatment recommendations for the animals in the care of the shelter. 180 Medical notes created by the students are recorded on a patient examination form (Figure 1) and 181 inserted into the patient's file at the shelter for future use by the shelter, potential adopters and veterinarians. Physical examination findings, diagnostic procedure results, and treatment recommendations are also catalogued into a digital format for data collection and case number reporting. 
Figure 1. Patient Examination Form used on CVS medial days.

Shelter Name:
Date:
Intake Date:
Species:
Patient Name:

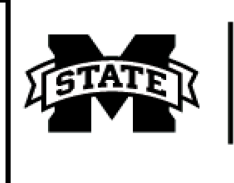

\begin{tabular}{|c|c|c|c|c|c|}
\hline \multicolumn{6}{|l|}{ Signalment/History: } \\
\hline Breed: & Appetite: & $\mathrm{NA}$ & Urination: & $\mathrm{NA}$ & Heartworm Status: \\
\hline Color: & Water Intake: & $\mathrm{NA}$ & Vomiting: & No Yes & Unkn Neg Pos N/A \\
\hline Age: & Attitude: & $\mathrm{NA}$ & Coughing: & No Yes & FIV/FELV Status: \\
\hline$M \square F \square$ Altered $\square$ & Feces: & $\mathrm{NA}$ & Sneezing: & No Yes & Unkn Neg Pos N/A \\
\hline \multicolumn{6}{|c|}{ Known Pre-Existing Diseases and Current Medications: } \\
\hline
\end{tabular}

\section{Physical Exam:}

Temp (f):____ Pulse Rate: Respiratory Rate: Weight (lb): BCS (1-9): Fecal Score (1-7):

General Appearance: N A

Eyes: N A Ocular Discharge $\square$

Ears: N A Otic Inflammation] Ear Mites $\square$

Respiratory: N A Nasal Discharge $\square$ Abnormal Lung Sounds $\square$

Oral Exam: N A Periodontal Disease (Grade 1234 ) $\square$ Oral Ulcers $\square$ Stomatitis $\square$

Lymph Nodes: $N$ A

Cardiovascular: N A Murmur (Grade 123456 )

Abdomen: N A Distended $\square$

Genitourinary: N A

Skin: N A Alopecia $\square$ Pruritus $\square$ Scales/Crusts/Collarettes $\square$

Musculoskeletal: N A

Neurological: N A

Other Exam Findings: Fleas $\square$ Ticks $\square$ Tapeworms $\square$

Examination/Diagnostic Tests/Doctor's Notes:

Fecal Flotation:

Student:

Faculty:

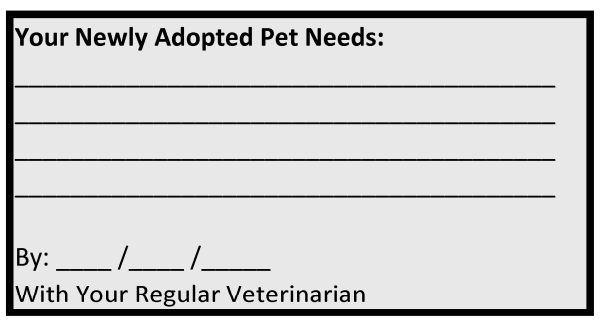

In addition to direct patient care, students also gain experience and knowledge of biosecurity during shelter medical days. Faculty lead students through the shelter for a biosecurity walk-through evaluation. After discussing biosecurity as a group, students participate in a biosecurity photoscavenger-hunt. Numerous examples of good and poor biosecurity are documented in photographic format and are later discussed in a round-table format. Students lead problem-based discussions to solve biosecurity issues that they encounter during the photo-scavenger-hunt.

At least 1 trip for each student is a shelter behavioral health day. Students are exposed to routine behavioral health, safe/low stress handling techniques and enrichment techniques. Shelter behavioral 
health days operate similarly to shelter medical days, but $>50 \%$ of the day is spent working through behavioral concepts and cases. Students are accompanied to the shelter by a MSU clinical instructor in behavioral medicine. Students are introduced to reading animal body language, non-stressful handling techniques, enrichment strategies, behavior assessments, and basic training strategies. Students also work though more complex behavior cases and develop treatment protocols involving training, enrichment, and sometimes pharmacologic intervention.

Students that participate in the shelter medical days are very positive about the experience and leave with greater confidence in performing physical exams, point-of-care diagnostics and treatment plan development. The following is an excerpt from a student evaluation:

"This has been my absolute favorite thing to do in vet school. We get hands on experience and I felt like I was actually making an impact and using the skills I have learned... I felt that all the clinicians were encouraging and helped answer any questions you had, while also trying to get you to think and problem solve on your own. I wish I could do this every day!"

Shelter medical days provide a large number of cases for veterinary students at MSU-CVM. Each student in the MSU-CVM class of 2016 evaluated an average of 8 patients and performed an average of 16 procedures/diagnostic tests during their CVS medical/behavioral days. As a whole, the class of 2016 evaluated 674 patients and performed 1359 procedures/diagnostic tests. Each student in the class of 2017 evaluated an average of 9 patients and performed 20 procedures/diagnostic tests. The class of 2017 evaluated 785 patients and performed 1691 procedures/diagnostic tests. While many animals are young and relatively free of serious disease processes, the chance to gain a solid knowledge base of normal physical examination findings builds a foundation for future cases. Furthermore, the repetition of multiple cases aids in improving diagnostic and technical skills.

Students are given direct feedback through hands-on instruction during shelter visits along with formal evaluations using an objective structured assessment (Appendix C.) Students receive 40 total possible points for shelter medical days that account for $10 \%$ of their overall CVS rotation grade.

\section{Population Medicine}

Veterinarians, no matter what their area of interest or expertise, will find themselves addressing animal health issues both at the individual and population level. Private practitioners whose main responsibilities lie with treating and preventing disease in individual patients need a working knowledge of biosecurity on a population level in order to minimize the risk of infectious diseases spreading to healthy populations. Students receive this training in a required 3-week Population Medicine rotation and learning is guided by five core principles (Table 3).

Table 3. Core Learning Principles in Population Medicine Rotation

Core Principles

Learning how the "system affects animal health outcomes

\section{Secondary objectives}

Rules, regulations, policy

Human and natural resources, capital

Personal decisions

\section{Thinking critically about causation}

Application to outbreak investigations

Evaluation of scientific literature 


$\begin{array}{ll}\begin{array}{l}\text { Utilizing diagnostic tests in population- } \\ \text { based disease investigations }\end{array} & \begin{array}{l}\text { Predictive value } \\ \text { Herd/population-level testing }\end{array}\end{array}$

\section{Using data (evidence) to investigate/monitor population health}

\author{
Data collection \\ Organizing data \\ Graphing data \\ Inferential statistics
}

\section{Implementing and communicating strategies for disease control and prevention}

Increase immunity

Prevent effective contacts

Remove the agent/keep the agent out

This rotation teaches the concepts across a variety of species, including cattle, swine, catfish, chickens, dogs and cats. The shelter program plays a large role in this rotation, as the students are on-site in a shelter for at least 3-4 trips per rotation. The students' first shelter visit of the rotation is focused on providing care for dogs at intake through preventive care, screening for signs of disease, and establishing or following biosecurity protocols. The second visit to another shelter exposes them to a variety of shelter systems. The culmination of their time in shelters during the Population Medicine rotation occurs when the students take part in on-site targeted consults, comprehensive shelter consults, or outbreak investigations.

Between June 2016 and August 2017, 15 onsite consultations were conducted with shelters or animal holding facilities. Shelters reach out to the faculty of the Population Medicine rotation seeking answers to questions regarding disease control, shelter management or animal health needs. Students play an important role in the consultation or outbreak investigation. Guided by faculty members, they collect data and gather specific information regarding the concerns of the shelter employees or the disease process of interest. Following participation in the consultation or outbreak investigation, the students analyze the data, gather credible scientific literature, and form recommendations regarding the issues. Working with faculty, the students learn another important principle: concise and constructive communication. It is the responsibility of the students to draft an initial recommendation letter that, after review and editing by faculty, will be submitted to the shelter.

\section{Challenges}

Challenges exist in the MSU-CVM Shelter Medicine program. Providing mobile veterinary care to area shelters across north Mississippi requires a flexible approach by teaching faculty and staff. Three full-time faculty along with available house officers are responsible for approximately 9,000 teaching cases per year. This requires creative scheduling to ensure quality teaching and contact time for the students involved. Under the umbrella of the Shelter Medicine Program, there are many activities - often each happening at the same time, but in different locations. Therefore, having the necessary veterinary and technical man-power is required to ensure program success. Beyond personnel, vehicle and trailer maintenance and mechanical failures can become difficulties, sometimes completely disrupting a day's activities. Routine preventive maintenance must be performed, therefor a 2-week hiatus from road trips in July and December provides the necessary time for servicing needs.

Post-operative care for surgical patients must be accomplished by shelter personnel due to the mobile nature of the program. To ensure high quality medical care for all patients, each shelter is required to have a local veterinarian agree to manage post-operative medical needs. Follow-up from 
269 MSU-CVM faculty is accomplished through routine email and phone communications to shelter personnel and local veterinarians when complications do occur.

Relying on shelters and humane organizations to provide animals and cases for student experience, like relying on a client-based caseload, can be a frustrating scenario. Objective structured assessments are a priority for the faculty, but every student cannot be guaranteed the same learning experiences due to the variable case load between animal shelters. For example, one student may perform three adult dog castrations during their two-week surgical elective while another student may perform 20 adult dog castrations. Similarly, students can become frustrated because they do not get to see the outcome of surgical and medical cases. Furthermore, one group of students may handle an initial population medicine consult by delivering the initial communication and recommendations, while a later group provides the follow up visit and benefits from seeing the end results. 


\section{Conclusions}

Animal shelters and humane organizations offer opportunities that can be mutually beneficial for both the animal organization and veterinary students. Students gain valuable experience and confidence that prepares them for their career, and shelters are provided with animal health care and consultative services that otherwise would not have been attainable. The overall caseload for the teaching institution is positively impacted, and goodwill is fostered in the communities served.

Author Contributions: All four authors contributed substantially to the authorship of this paper.

291 Conflicts of Interest: The authors declare no conflict of interest.

\section{Appendix A} points possible.

\begin{tabular}{|c|c|c|c|c|c|}
\hline Skill & 1 & 2 & 3 & 4 & 5 \\
\hline Understanding anatomy & $\begin{array}{l}\text { Not familiar with } \\
\text { surgical anatomy }\end{array}$ & $\begin{array}{l}\text { Struggles with } \\
\text { understanding of } \\
\text { surgical anatomy }\end{array}$ & $\begin{array}{l}\text { Understands the } \\
\text { anatomy of most } \\
\text { structures } \\
\text { encountered }\end{array}$ & $\begin{array}{l}\text { Understands } \\
\text { all major } \\
\text { structures } \\
\text { encountered }\end{array}$ & $\begin{array}{l}\text { Full } \\
\text { understanding } \\
\text { of anatomy } \\
\text { related to } \\
\text { surgery }\end{array}$ \\
\hline $\begin{array}{l}\text { Understanding surgical } \\
\text { procedure }\end{array}$ & $\begin{array}{l}\text { Not familiar with } \\
\text { the surgical } \\
\text { procedure }\end{array}$ & $\begin{array}{l}\text { Struggles with } \\
\text { understanding of } \\
\text { surgical procedure }\end{array}$ & $\begin{array}{l}\text { Understands the } \\
\text { basic surgical } \\
\text { procedure }\end{array}$ & $\begin{array}{l}\text { Understands } \\
\text { the surgical } \\
\text { procedure } \\
\text { completely }\end{array}$ & $\begin{array}{l}\text { Full } \\
\text { understanding, } \\
\text { including } \\
\text { alternatives } \\
\text { and potential } \\
\text { complications }\end{array}$ \\
\hline Attention to asepsis & $\begin{array}{l}\text { Does not } \\
\text { understand/ } \\
\text { follow aseptic } \\
\text { technique }\end{array}$ & $\begin{array}{l}\text { Problems with } \\
\text { aseptic technique; } \\
\text { required repeated } \\
\text { instructor } \\
\text { intervention }\end{array}$ & $\begin{array}{l}\text { Pays attention to } \\
\text { aseptic technique; } \\
\text { minor breaks } \\
\text { corrected by } \\
\text { instructor }\end{array}$ & $\begin{array}{l}\text { Attention to } \\
\text { asepsis; } \\
\text { breaks in } \\
\text { asepsis noted } \\
\text { and } \\
\text { corrected }\end{array}$ & $\begin{array}{l}\text { Absolute } \\
\text { attention to } \\
\text { asepsis; no } \\
\text { breaks in } \\
\text { sterile } \\
\text { technique } \\
\text { noted }\end{array}$ \\
\hline $\begin{array}{l}\text { Prevention/control of } \\
\text { hemorrhage }\end{array}$ & $\begin{array}{l}\text { Does not follow } \\
\text { appropriate } \\
\text { techniques for } \\
\text { prevention/control } \\
\text { of hemorrhage }\end{array}$ & $\begin{array}{l}\text { Problems with } \\
\text { management of } \\
\text { hemorrhage; } \\
\text { required repeated } \\
\text { instructor } \\
\text { intervention }\end{array}$ & $\begin{array}{l}\text { Minor problems } \\
\text { with hemorrhage } \\
\text { that required } \\
\text { intervention by } \\
\text { instructor }\end{array}$ & $\begin{array}{l}\text { Consistently } \\
\text { manages } \\
\text { hemorrhage } \\
\text { with no risk } \\
\text { to the patient }\end{array}$ & $\begin{array}{l}\text { Consistently } \\
\text { prevents } \\
\text { hemorrhage } \\
\text { before it } \\
\text { occurs }\end{array}$ \\
\hline
\end{tabular}




\begin{tabular}{|c|c|c|c|c|c|}
\hline $\begin{array}{l}\text { Minimizing tissue } \\
\text { trauma }\end{array}$ & $\begin{array}{l}\text { Tissue severely } \\
\text { damaged } \\
\text { unnecessarily }\end{array}$ & $\begin{array}{l}\text { Inadvertent } \\
\text { trauma to } \\
\text { structures not } \\
\text { routinely involved } \\
\text { in the surgical } \\
\text { procedure }\end{array}$ & $\begin{array}{l}\text { Frequent } \\
\text { unnecessary tissue } \\
\text { manipulation } \\
\text { resulting in } \\
\text { considerable tissue } \\
\text { trauma }\end{array}$ & $\begin{array}{l}\text { Occasional } \\
\text { tissue } \\
\text { manipulation; } \\
\text { slight } \\
\text { increase in } \\
\text { tissue trauma }\end{array}$ & $\begin{array}{l}\text { Minimal tissue } \\
\text { trauma }\end{array}$ \\
\hline $\begin{array}{l}\text { Efficiency of surgical } \\
\text { skills }\end{array}$ & $\begin{array}{l}\text { Considerable } \\
\text { wasted motion, } \\
\text { indecisive; surgical } \\
\text { time excessive }\end{array}$ & $\begin{array}{l}\text { Frequent wasted } \\
\text { motions/indecision }\end{array}$ & $\begin{array}{l}\text { Occasional wasted } \\
\text { motions/indecision }\end{array}$ & $\begin{array}{l}\text { Surgery } \\
\text { performed } \\
\text { efficiently; } \\
\text { minimal } \\
\text { wasted } \\
\text { motion }\end{array}$ & $\begin{array}{l}\text { Surgery } \\
\text { performed } \\
\text { with utmost } \\
\text { efficiency; no } \\
\text { wasted } \\
\text { motions }\end{array}$ \\
\hline $\begin{array}{l}\text { Surgical } \\
\text { competence/confidence }\end{array}$ & $\begin{array}{l}\text { Confidence in } \\
\text { surgical skills is } \\
\text { unwarranted; } \\
\text { lacks basic surgical } \\
\text { skills necessary for } \\
\text { minor/routine } \\
\text { procedures }\end{array}$ & $\begin{array}{l}\text { Lacks confidence } \\
\text { in surgical skills; } \\
\text { lacks basic surgical } \\
\text { skills necessary for } \\
\text { minor/routine } \\
\text { procedures }\end{array}$ & $\begin{array}{l}\text { Competent in } \\
\text { many aspects of } \\
\text { surgical procedure }\end{array}$ & $\begin{array}{l}\text { Competent in } \\
\text { most aspect } \\
\text { of surgical } \\
\text { procedure; } \\
\text { minor } \\
\text { problems as } \\
\text { described } \\
\text { below }\end{array}$ & $\begin{array}{l}\text { Confident in } \\
\text { surgical skills; } \\
\text { very } \\
\text { competent } \\
\text { skills }\end{array}$ \\
\hline & Pass & & Fail & & \\
\hline Patient care & \multicolumn{5}{|c|}{$\begin{array}{l}\text { All students are expected to provide thorough and competent care for their patients. This is } \\
\text { a threshold skill. }\end{array}$} \\
\hline Professional attributes & \multicolumn{5}{|c|}{$\begin{array}{l}\text { All students are expected to communicate effectively with clients, technicians, and faculty, to } \\
\text { complete medical records and surgery reports accurately and expeditiously and to act } \\
\text { professionally at all times. }\end{array}$} \\
\hline
\end{tabular}

\section{Appendix B}

296 Objective Structured Assessment of Fourth Year Students

\begin{tabular}{|c|c|c|c|c|}
\hline Student & & & & \\
\hline Date & & & & \\
\hline Grade & & & & \\
\hline Surgical Skills & Description & Value & Score & Comment \\
\hline
\end{tabular}




\begin{tabular}{|c|c|c|c|c|}
\hline $\begin{array}{l}\text { Understands each } \\
\text { procedure }\end{array}$ & $\begin{array}{l}\text { Understands the basics of each } \\
\text { procedure at the start of the rotation } \\
\text { (i.e. has thoroughly reviewed the } \\
\text { PowerPoints and videos) }\end{array}$ & 10 & & \multirow{9}{*}{$\begin{array}{l}\text { Remember, every skill you need } \\
\text { for virtually any soft-tissue } \\
\text { surgery commonly done in } \\
\text { private practice, you use in a } \\
\text { spay. So if you are comfortable } \\
\text { doing spays, you have the skills to } \\
\text { perform any routine soft-tissue } \\
\text { surgery! }\end{array}$} \\
\hline Applies what is learned & $\begin{array}{l}\text { Applies what is learned each day to } \\
\text { subsequent surgeries, i.e. doesn't } \\
\text { repeat mistakes. }\end{array}$ & 10 & & \\
\hline Detail & $\begin{array}{l}\text { Thinks about what he/she is doing. } \\
\text { Pays attention to detail. Performs } \\
\text { tasks appropriately. }\end{array}$ & 10 & & \\
\hline Efficient surgical skills & $\begin{array}{l}\text { Adopts efficient techniques. Shows } \\
\text { improvement in efficiency over the } \\
\text { course. }\end{array}$ & 10 & & \\
\hline Maintains hemostasis & Effectively prevents hemorrhage. & 10 & & \\
\hline Minimizes tissue trauma & Treats tissues gently. & 10 & & \\
\hline Maintains asepsis & Pays attention to maintaining asepsis. & 10 & & \\
\hline Closures & $\begin{array}{l}\text { Secure body wall closures. } \\
\text { Consistently closes dead space. Good } \\
\text { skin to skin apposition with } \\
\text { subcuticular patterns. }\end{array}$ & 10 & & \\
\hline \multicolumn{2}{|l|}{ Total Points from Rotation } & 80 & & \\
\hline Exam & & 20 & & \\
\hline Total points & & 100 & & \\
\hline $\begin{array}{l}\text { Professional Values/ } \\
\text { Behavior* }\end{array}$ & & pass & fail & \\
\hline Animal care & $\begin{array}{l}\text { Treats all animals with respect. } \\
\text { Handles animals appropriately. }\end{array}$ & $\checkmark$ & & \\
\hline Attendance punctuality & Arrives on time. & v & & \\
\hline Overall initiative & Pitches in to get all the work done. & $v$ & & \\
\hline
\end{tabular}




\begin{tabular}{|l|l|l|l|l|}
\hline Attitude & Positive friendly attitude. & $V$ & & \\
\hline Professionalism & $\begin{array}{l}\text { Acts professional. Positive } \\
\text { representative of Mississippi State and } \\
\text { the Veterinary Profession. }\end{array}$ & $\mathrm{V}$ & & \\
\hline
\end{tabular}

\section{Appendix C}

298 Objective Structured Assessment for CVS Medical Days. Each skill is graded 1-5 with a totoal of 40 299 points possible.

\begin{tabular}{|c|c|c|c|c|c|}
\hline Skill & 1 & 2 & 3 & 4 & 5 \\
\hline $\begin{array}{l}\text { Understanding ASV Shelter } \\
\text { Guidelines }\end{array}$ & $\begin{array}{l}\text { Not familiar at } \\
\text { all with ASV } \\
\text { Shelter } \\
\text { guidelines. }\end{array}$ & $\begin{array}{l}\text { Struggles with } \\
\text { understanding } \\
\text { of guidelines. }\end{array}$ & $\begin{array}{l}\text { Understands } \\
\text { most of the } \\
\text { basic shelter } \\
\text { principles in the } \\
\text { guidelines. }\end{array}$ & $\begin{array}{l}\text { Understands } \\
\text { all major } \\
\text { principles } \\
\text { encountered } \\
\text { in the ASV } \\
\text { guidelines. }\end{array}$ & $\begin{array}{l}\text { Full } \\
\text { understanding } \\
\text { of guidelines; } \\
\text { able to apply } \\
\text { principles to } \\
\text { current shelter. }\end{array}$ \\
\hline $\begin{array}{l}\text { Understanding biosecurity } \\
\text { principles/photo scavenger } \\
\text { hunt }\end{array}$ & $\begin{array}{l}\text { Not familiar } \\
\text { with } \\
\text { biosecurity } \\
\text { principles. }\end{array}$ & $\begin{array}{l}\text { Struggles with } \\
\text { understanding } \\
\text { of biosecurity } \\
\text { principles. }\end{array}$ & $\begin{array}{l}\text { Understands } \\
\text { basic biosecurity } \\
\text { principles. } \\
\text { Limited } \\
\text { understanding } \\
\text { of fine details } \\
\text { biosecurity } \\
\text { principles. }\end{array}$ & $\begin{array}{l}\text { Understands } \\
\text { biosecurity } \\
\text { principles } \\
\text { completely, } \\
\text { familiar with } \\
\text { fine details. }\end{array}$ & $\begin{array}{l}\text { Full } \\
\text { understanding } \\
\text { of all aspects of } \\
\text { shelter } \\
\text { biosecurity } \\
\text { principles and } \\
\text { application to } \\
\text { current shelter. }\end{array}$ \\
\hline Physical examination & $\begin{array}{l}\text { Does not know } \\
\text { how to } \\
\text { perform a } \\
\text { physical } \\
\text { examination. }\end{array}$ & $\begin{array}{l}\text { Attempts a PE, } \\
\text { but struggles, } \\
\text { requiring } \\
\text { repeated } \\
\text { instructor } \\
\text { intervention for } \\
\text { basic principles. }\end{array}$ & $\begin{array}{l}\text { Performs PE } \\
\text { well, but } \\
\text { occasionally } \\
\text { misses body } \\
\text { systems or } \\
\text { abnormal } \\
\text { findings. }\end{array}$ & $\begin{array}{l}\text { Performs PE } \\
\text { well. }\end{array}$ & $\begin{array}{l}\text { Performs PE } \\
\text { extremely well, } \\
\text { covering all body } \\
\text { systems and } \\
\text { abnormal } \\
\text { findings. }\end{array}$ \\
\hline $\begin{array}{l}\text { Fecal float technique and } \\
\text { analysis }\end{array}$ & $\begin{array}{l}\text { Does not } \\
\text { understand } \\
\text { how to } \\
\text { perform fecal } \\
\text { float or } \\
\text { analysis. }\end{array}$ & $\begin{array}{l}\text { Problems with } \\
\text { fecal float } \\
\text { technique and } \\
\text { analysis. } \\
\text { Required } \\
\text { repeated } \\
\text { instructor } \\
\text { intervention. }\end{array}$ & $\begin{array}{l}\text { Minor problems } \\
\text { with fecal float } \\
\text { technique and } \\
\text { analysis. } \\
\text { Misses most } \\
\text { organisms with } \\
\text { analysis. }\end{array}$ & $\begin{array}{l}\text { Fecal float and } \\
\text { analysis } \\
\text { performed } \\
\text { well. Most } \\
\text { organisms ID'd } \\
\text { correctly. }\end{array}$ & $\begin{array}{l}\text { Performs fecal } \\
\text { float and } \\
\text { analysis } \\
\text { extremely well. } \\
\text { All organisms } \\
\text { ID'd correctly. }\end{array}$ \\
\hline
\end{tabular}




\begin{tabular}{|c|c|c|c|c|c|}
\hline Differential diagnosis & $\begin{array}{l}\text { No effort to } \\
\text { create } \\
\text { differential } \\
\text { diagnosis when } \\
\text { warranted. }\end{array}$ & $\begin{array}{l}\text { Differential } \\
\text { diagnosis } \\
\text { attempted. }\end{array}$ & $\begin{array}{l}\text { Differential } \\
\text { diagnosis } \\
\text { created, but } \\
\text { incomplete. } \\
\text { Major diseases } \\
\text { not included. }\end{array}$ & $\begin{array}{l}\text { Differential } \\
\text { diagnosis list } \\
\text { created, only } \\
\text { minor diseases } \\
\text { not included. }\end{array}$ & $\begin{array}{l}\text { Excellent } \\
\text { differential } \\
\text { diagnosis list; } \\
\text { complete and } \\
\text { thorough. }\end{array}$ \\
\hline Diagnostic plan/abilities & $\begin{array}{l}\text { Does not } \\
\text { understand } \\
\text { how to } \\
\text { formulate } \\
\text { diagnostic } \\
\text { plan. }\end{array}$ & $\begin{array}{l}\text { Problems with } \\
\text { forming plan } \\
\text { and unable to } \\
\text { perform } \\
\text { recommended } \\
\text { tests. Required } \\
\text { repeated } \\
\text { instructor } \\
\text { intervention. }\end{array}$ & $\begin{array}{l}\text { Minor problems } \\
\text { with forming } \\
\text { plan and } \\
\text { completing } \\
\text { diagnostics } \\
\text { tests. Only some } \\
\text { organisms } \\
\text { identified } \\
\text { correctly. }\end{array}$ & $\begin{array}{l}\text { Consistently } \\
\text { forms } \\
\text { excellent plan, } \\
\text { but } \\
\text { occasionally } \\
\text { has problems } \\
\text { with } \\
\text { performing } \\
\text { diagnostic } \\
\text { tests. Most } \\
\text { organisms ID'd } \\
\text { correctly. }\end{array}$ & $\begin{array}{l}\text { Creates } \\
\text { diagnostic plan } \\
\text { and performs } \\
\text { diagnostics very } \\
\text { well. All } \\
\text { organisms ID'd } \\
\text { correctly. }\end{array}$ \\
\hline Treatment plan & $\begin{array}{l}\text { No effort to } \\
\text { create } \\
\text { treatment plan } \\
\text { when } \\
\text { warranted. }\end{array}$ & $\begin{array}{l}\text { Treatment plan } \\
\text { attempted, but } \\
\text { instructor } \\
\text { intervention } \\
\text { necessary. }\end{array}$ & $\begin{array}{l}\text { Treatment plan } \\
\text { created, but } \\
\text { incomplete and } \\
\text { major diseases } \\
\text { not addressed; } \\
\text { instructor } \\
\text { intervention } \\
\text { necessary. }\end{array}$ & $\begin{array}{l}\text { Treatment } \\
\text { plan created, } \\
\text { minor details } \\
\text { addressed and } \\
\text { corrected. }\end{array}$ & $\begin{array}{l}\text { Excellent } \\
\text { treatment plan; } \\
\text { complete and } \\
\text { thorough. Able } \\
\text { to present plan } \\
\text { to shelter } \\
\text { personnel. }\end{array}$ \\
\hline $\begin{array}{l}\text { Preventative medicine / } \\
\text { general wellness }\end{array}$ & $\begin{array}{l}\text { No effort to } \\
\text { create general } \\
\text { wellness plan. }\end{array}$ & $\begin{array}{l}\text { Lacks } \\
\text { understanding } \\
\text { of general } \\
\text { wellness (vacc. } \\
\text { protocols, etc.) }\end{array}$ & $\begin{array}{l}\text { Competent in } \\
\text { many aspects of } \\
\text { preventive } \\
\text { medicine and } \\
\text { wellness care. }\end{array}$ & $\begin{array}{l}\text { Competent in } \\
\text { most aspects } \\
\text { of preventive } \\
\text { medicine and } \\
\text { wellness. }\end{array}$ & $\begin{array}{l}\text { Confident and } \\
\text { competent in } \\
\text { creating and } \\
\text { recommending } \\
\text { general wellness } \\
\text { plans to shelter } \\
\text { personnel. }\end{array}$ \\
\hline Comments & & & & & \\
\hline
\end{tabular}


302

303

304

305

306

307

308

309

310

311

312

313

314

\section{References}

1. Hubbell, J.A. Veterinary teaching hospitals: Current challenges and pathways for the future. J Vet Med Educ 2008, 35, 62-65.

2. Freeman, L.J.; Ferguson, N.; Litster, A.; Arighi, M. Service learning: Priority 4 paws mobile surgical service for shelter animals. J Vet Med Educ 2013, 40, 389-396.

3. Griffin, B.; Bushby, P.A.; McCobb, E.; White, S.C.; Rigdon-Brestle, Y.K.; Appel, L.D.; Makolinski, K.V.; Wilford, C.L.; Bohling, M.W.; Eddlestone, S.M. The association of shelter veterinarians' 2016 veterinary medical care guidelines for spay-neuter programs. J Am Vet Med Assoc 2016, 249, 165-188.

4. Newbury, S.; Blinn, M.K.; Bushby, P.A.; Cox, C.B.; Dinnage, J.D.; Griffin, B.; Hurley, K.F.; Isaza, N.; Jones, W.; Miller, L. Guidelines for standards of care in animal shelters. The Association of Shelter Veterinarians 2010, 1-45. 